\title{
HOW TO SELL ISLAMIC STUDIES IN HIGHER EDUCATION (INTEGRATED MARKETING COMMUNICATION OF FACULTY OF ISLAMIC STUDIES IN UNIVERSITAS ISLAM INDONESIA)
}

\author{
Ratna Permata Sari
}

\author{
Universitas Islam Indonesia
}

\begin{abstract}
Talk about education, which comes in mind of course the things that are academic, curriculum, exams and others. But what about the education in private university? In contrast to public universities that are relatively easier to get prospective students, private university has to issue a proper strategy to grab the attention of prospective students, because the biggest source of college revenue still comes from students. Universitas Islam Indonesia (UII) as the oldest Indonesian national university has eight faculties and international program also would have to determine measures to sell the study programs with elegant way. In this case, researcher focused on Faculty of Islamic Studies as the oldest faculty in this campus. As the old faculty with major that characterized by religion certainly has its own challenges to sell their study programs. The fierce competition of universities in Yogyakarta and Indonesia inevitably makes Faculty of Islamic Studies (FIAI) UII should conduct integrated marketing communication strategies to increase the number of applicants in each of the three study programs. This research was conducted with a qualitative descriptive method to know what kind of integrated marketing strategies that FIAI do to attract potential new registrants based on suitable market target of the study programs.
\end{abstract}

Keywords: Islamic Studies, marketing, UII

\section{Introduction}

In the current era, the role of education becomes important. Education became a secondary requirement after food, clothing and shelter. That is why from year to year the number of schools and colleges more multiply. The number and variant courses that opened at the university level is also growing. Competition among college became inevitable. Not only campus in the same region, but also from other regional, and with overseas campuses.

Moreover, competition for fellow private colleges increasingly visible. Some claim the top ranking universities from several different sources is evident from the sale are shown. Starting from the ranking list of the best universities in Indonesia according to BAN-PT (National Accreditation Board - Higher Education), Webometrics, QS Star, 4icu, times, higher education, and so forth. Real competition was conducted to get a lot of applicants and the number of new students with good quality.

Universitas Islam Indonesia as the oldest national campus in Indonesia certainly cannot relax the face of competition between colleges. Although In achievement, in 2013 UII scored institutional accreditation or excellent A among private universities. And overall with universities and private colleges, the university won the sixth (UII raih akreditasi institusi tertinggi PTS, 2015). UII as an institution would have to think about strategies to fully take part in the competition.

Universitas Islam Indonesia (UII) which currently located in the city of Yogyakarta is the oldest national campus in Indonesia which was established on July 8, 1945. Now, UII has eight faculty, such as faculty of economic, faculty of law, faculty of Islamic studies, faculty of medicine, faculty of mathematics and natural sciences, faculty of psychology and socio- 
cultural sciences, faculty of civil enineering and planning, faculty of industrial technology and International program.

Faculty of Islamic studies as one of the oldest faculties at UII, and brought Islamic studies course has its own obstacles to face the challenges of the current era. Indonesia as one of the countries with the largest number of Muslims in the world would have big consequences. One of them can be seen with so many events that religion, particularly Islam makes indirect impact on the image of Islam. In addition there are so many schools and Islamic organizations as if boxing Islam of their own ideas of interest.

Now Faculty of Islamic Studies (FIAI) has three programs in bachelor degree such as Islamic Education, Islamic Law and Islamic Economy. In master degree, faculty of Islamic Studies has master of Islamic and doctoral of Islamic Law. Interesting to focus research in this faculty, because as one of the oldest faculties at UII but it is the number of students is not too flashy. According to data from unisys.uii.ac.id, the amount in FIAI before the year 2010 in each program of study per batch of about 30 to 50 students. It can be said for a small number of study programs at private colleges, considering most of the operational funds and university courses are still dependent on the number of students.

But the passage of time, gradually the number of students admitted in FIAI began to grow. Total students in three majors in the faculty that in 2010 there were 129 students, in 2011 there are 159 students, in 2013 there was an increase of about $59 \%$ and a big spike in the last three years from 421 students, and 578 and 2015 get 562 students (Rekapitulasi status mahasiswa per program studi, 2016).

An achievement that cannot be underestimated with the addition of a significant number of students to faculty who had underestimated this. Manager of faculty absolutely think about promotion and marketing strategies to increase the number of students of the three courses. When viewed from the marketing theory, in determining the marketing strategy as for the steps to be taken to see the fit between market, product and general public awareness. According to Adam Smith (in Tjiptono,
2015: 1) he explains the marketing strategy is seen as a general statement about the direction in selecting target markets and designing and implementing marketing mix. The three main aspects covered are where to Compete (determination of the company selected markets), on what basis to Compete (development of products and services), as well as when to Compete (timing to enter the market and market development activities). Broadly speaking, this study will analyze the marketing strategy of faculty of Islamic Studies and cross checked with the theory of integrated marketing communication.

Based on that background problem, researcher became interested in researching this topic. As for the question of this research is how the marketing strategy of the faculty of islamic studies UII in increasing the number of students?

\section{Research Methodology}

The study was a descriptive study with qualitative approach and constructivism paradigm. Qualitative research seeks to understand an event through knowledge. This approach always put the process rather than results. This approach can provide details about the findings of a more complex phenomenon that is difficult to express the quantitative approach. This paradigm considers that the fact that the results of construction or build from the man himself. The fact is a double, can be formed, and is one wholeness. The fact there is as a result of the formation of a person's ability to think. The results obtained from this study in the form of narration, description, photos are not numbers or statistics in quantitative research.

The object of this study is the faculty of Islamic studies in Universitas Islam Indonesia. For data collection techniques are observation, indept interview and litetature review. In this study, respondent selection technique is purposive sampling where researchers had previously select respondents based on several considerations are of course tailored to the needs of research data. Researchers conducted interviews with five respondents. Name respondents include: Rizka Amalia Shofa, S.Pd. I as a public relations and student staff of dean Faculty of Islamic Studies, Muhammad Safarullah as the main coordinator marketing communication (marcom) of faculty of islamic studies, Siti Annisa Rahmayani as 
public relations marcom, Kurnia alifiani as marcom secretary and Krisnanda as chairman of the division of social media in marcomm FIAI

\section{Discussion}

\section{Situation Analysis}

By looking at the real data about the increasing number of students FIAI significantly in recent years, it is interested in to examine what kind of the marketing communication strategy that they did adapted to the integrated marketing communication theory.

In the analysis of marketing, in an early stage we need to analyze the situation to determine the marketing and communication objectives. While the promotional mix strategies designed to achieve both these goals. First it is important to recognize who the consumers of the company. Since the concept of segmentation gives a handle which is very important in marketing that suggestion to choose a particular part of a very broad consumer audience in order to provide the best possible service (Morrisan, 2010: 58).

Related to this study, when talking about the target market segmentation and new students, FIAI seems more appropriate we ask the right person, she is Dra. Hj. Sri Hariningsih, M.Ag as vice dean FIAI the period 2014- 2018. She said that: "Segmentation students of FIAI is comes from students of madrasah aliyah, and SMA Islam including Islamic boarding school that synergized with learning curriculum on FIAI"

In accordance with the theory of segmentation that must choose one or several segments of consumers only, in this case FIAI select students of Madrasah Aliyah, Islamic high school and boarding school with the consideration they have previously studied at the school on the basis of Islam, so likely they are also interested in continue studying in similar fields.

Speaking of segmentation that cannot be separated from the competitive analysis, FIAI also performs competitive analysis to see who the competitor is in the city of Yogyakarta and surrounding areas. Vice Dean FIAI explained that "STAIN, UIN is the average tuition fee. However FIAI tuition fee also inexpensive. Besides UII, in private university we have competitors such as Universitas Ahmad Dahlan(UAD) and Universitas Muhammadiyah Yogyakarta (UMY), but FIAI in UII have the strength as the oldest national university in Indonesia, has been accredited A and the cost is still affordable".

As competitors FIAI UII, there are two national campus in Jogja among others State Islamic School in Surakarta (Sekolah Tinggi Agama Islam Negeri) and Islamic State University in Yogyakarta (Universitas Islam Negeri) that has advantage for prospective new students in inexpensive tuition fees because the price aspect still an important point in determining the place of study. Meanwhile, the second competitor is another private university in Yogyakarta, among others UAD and UMY that because the tuition fee in the private college still slightly above the national campus. However, she explained that the cost of tuition fee at FIAI UII can also be said to be cheap or not too expensive, and FIAI has strength as the oldest national university, and obtain institutional accreditation A.

Judging from the number of students who initially did not much like students from other faculties, Rizka Amalia as FIAI marketing staff explained that:

"The market of religion program at several universities such as UII (where the field of non religious superior) still low. However, FIAI actually not the only one experiencing this condition. At the University of Ahmad Dahlan Yogyakarta also experienced the same thing. Religion faculty in campus was also not in high demand other faculties. Although the number of students in the FIAI UII itself is not much when compared to other faculties, but it turns out the number of students FIAI UII is still higher than religions faculty at other universities"

In preparing the strategy and marketing plans, marketing practitioners should perform a careful analysis of the existing competition in the market segment. People who focused on marketing should always pay attention to the situation of competition that always changing. The marketing program of the company's competitors may impact the company's own marketing strategy, so that competitors marketing program must continue to be analyzed and monitored (Morissan, 2014: 53). 
Segmentation also talk about how to respond to the market, what the market asking for so the company will provide it. In this case, we talk about the determination of tuition fee in FIAI UII when we related with the competitors. The Vice Dean of FIAI UII explained that "Tuition at FIAI determined by the university and cross-subsidies with other faculties in UII because tuition fee of FIAI is cost less than other faculties in consideration with competitors, such as with UIN that slightly cheap, so our tuition fee cannot too high".

She explained that the determination of tuition fees also need to consider with similar competitors. When compared with other faculties at UII, tuition in FIAI can be said to be lower because it is important to respond to the market that the market for study programs in FIAI can certainly reach the purchasing power of potential customers and because other competitors that have already dominated those segments have cheap tuition fee.

This is known as a competitive advantage that particulars of the company which makes it an advantage over competitors (Morissan, 2010: 53) by showing that FIAI UII has good quality because located on the oldest campus, accredited A, but because competitors tuition fees are not high so FIAI implement tuition fees are not too high as well.

\section{Promotional Mix}

Promotional mix elements carried by FIAI among others:

\section{a. Public Relations}

FIAI already focuses on marketing strategies for new admissions from previous years ago with the some ways such as each year (starting in 2011) select students to participate in the educational expo and promotional roadshow of FIAI UII. Although FIAI is one of the oldest faculties at UII, but it looks like the program of study in FIAI has not been heard in the widest range. So, needs to be considered that the sale promotion is one of the factors determining the success of a marketing program. Promotion is an element of the marketing mix focusing on efforts to

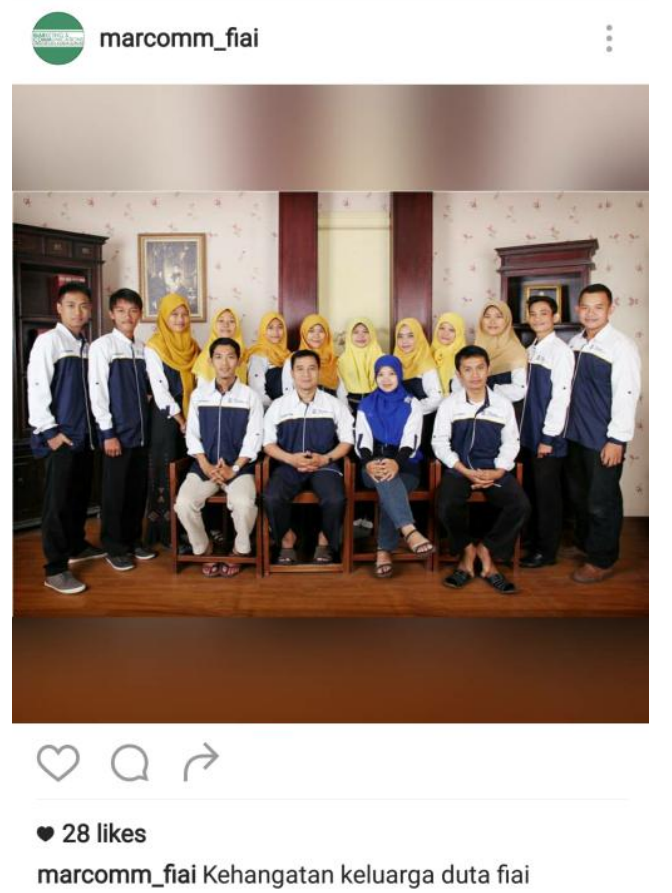

Figure 1: Marcomm FIAI First Generation

inform, persuade and remind consumers of their and the company's products (Tjiptono, 2015: 387). To deliver the promotional messages to the consumers, FIAI choose the students that has marketing capability as known as Marketing Communication of FIAI (FIAI).

Rizka Amalia, S.Ag as the staff of the public relations and promotional FIAI tells about the early formation of the marketing communication in this faculty:

"The early formation of Marcomm FIAI in 2014 was formed by Ms. Soya and Mr. Rozi who think they cannot did all of the promotion activities by themselves because they are as lecturer and faculty staff with a lot of routine task and other workload as well. And it was right time to form a specialized marketing promotions team of FIAI. They selected several students who has previous name as promotion ambassador of FIAI "

The establishment of Marcomm FIAI with the consideration that their age (students as Marcomm FIAI) closer with the high school students than lecturer or staff. Marcomm FIAI in the strategy of integrated marketing communications in the realm of public relations. According to Dominick, Public Relations (PR) in this case Marcomm FIAI must be an alternating current channels between organizations 
and their audience. PR is responsible to explain the company's actions to the public with an interest in the organization or company (Morissan, 2014: 28).

PR must also has a well-planned activity. Because PR should be able to organize and direct the division to achieve certain goals. In this case marcomm FIAI UII has a goal to increase the number of apllicants of the faculty. Siti Annisa said that to expedite the goals, Marcomm FIAI has several divisions such as logistics division which served to produce and determine the type of promotional tools, public relations are established good relationships with external stakeholder, the division of social media to optimize social media internet, a division of direct promotion services responsible for managing the process of dealing with the school's roadshow outside the city, and creative project division in charge of designing a promotional tool.

According to Dominick, PR includes all of things closely related to communication. That is why Marcomm FIAI as public relations need to think about how to communicate with consumers. Marcomm FIAI should give attention to the thoughts and feelings of consumers to FIAI. Marcomm FIAI as PR must be alternating current channel between faculty and their prospective consumers. To facilitate channel between the FIAI and consumers, marcom FIAI need to design divisions support the work of marcom. One of its divisions is the public relations division to establish communication with external parties, in particular, the task of Public Relation division in Marcomm FIAI UII is to establish a relationship with a variety of audiences, ranging from internal to external.

\section{b. Personal Selling}

Integrated marketing communication emphasizes dialogue organized with internal and external audiences that are personalized, customer-oriented and technology-driven. (Tjiptono, 2015: 387). "Before the establishment of Marcomm FIAI, strategy to promote FIAI by asking their students to return home town attended the education expo and did promotional presentation in their high schools (Rizka Amalia)" FIAI did customer retention by followed the education expo at the student's high school where it is oriented with relative or a close relationship that has existed between the alumni and the school that shared

experience can be more trusted by younger classes and the teachers of the school.
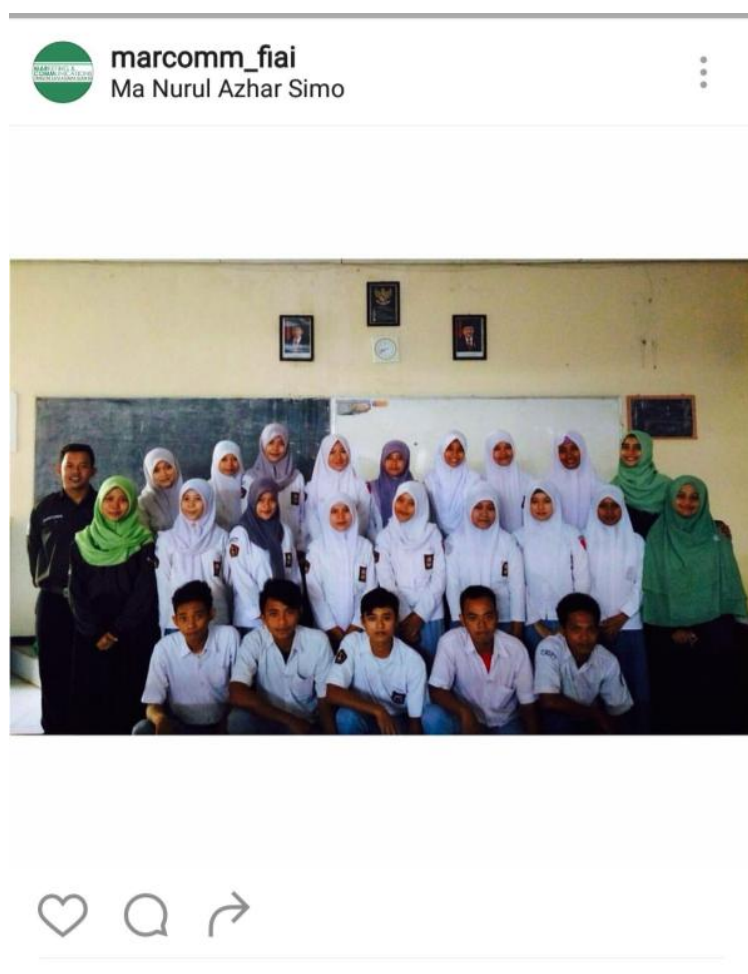

- 20 likes

marcomm_fiai Team Marcomm FIAI bersama anak2

MA Nurul Azhar, Kendal, Ngawi, Jawa Timur..

Figure 2:Roadshow by Marcomm FIAI to Roadshow Marcom FIAI ke MA Nurul Axhar, Ngawi

FIAI designed marketing strategy by direct approach to the target market by roadshow to Islamic school and follow the education expo"The reason why we choose roadshow because we realize that our market is different from other faculties market in UII, so we determine the target are comes from the Islamic Madrasah schools and boarding schools and we already realize that they are our prospective market. Considerations to select location of roadshow can be seen from where FIAI students come from, which is we can see from the data of new admissions "Roadshow conducted by Marcomm FIAI is already suitable with what has been specified from the beginning of the market segmentation FIAI. As explained by Ms. Vice Dean of FIAI UII that their segmentation is a graduate student of Madrasah Aliyah, Islamic boarding school and Islamic high 
school. And the selection of location roadshow based on the original data before freshman year in which it were easier to provide information about FIAI in place of their alumni who are currently studying in FIAI.

Because FIAI already determine that their segmentation is different from another faculties in UII, so from 2015 and early 2016, FIAI focused on roadshow to the area of West Java, Central Java, Yogyakarta and part of East Java among others Province of Central Java: MAN Magelang and MAN Al-Imam Mathla'ul Anwar Magelang, Province of West Java: MA Al-Masturiyah Sukabumi, SMA AlAtiqiyah Sukabumi, MAN Cibadak Sukabumi, MAN Sunanul Huda Sukabumi and MAN Cijeruk Bogor, Province of East Java: MAN 2 Madiun, MAN Miftahul Lubab Ngawi, MA Muhammadiyah 3 Ponorogo, and MA Nurul Azhar Ngawi. Special Regional of Yogyakarta: MAN Pakem and MA Muslimin Muhammadiyah Yogyakarta” (Kurnia).

Kurnia (as secretary of Marcomm FIAI) also explains what is described when they did roadshows to schools.

"When we did Roadshow at schools, we presented in general about Yogyakarta City as student city, achievement of UII, and departments in Faculty of Islamic Studies. We wanted to show the advantages of each departement. For example: Islamic Education department, if you study here what will you get, and and we will show that not just always study about the science of religion in general. For practical example, if you start the fasting month usually Just out of the confirmation hearings on television but they do not know the process rukhiyatul moon, and in department, they offered and facilitate the students to practice it directly "

By meet face-to-face with consumers, Marcomm FIAI can directly explain what they want to tell to consumers about the advantages FIAI and what will they obtained when they studied there. Additionally, Marcomm FIAI also gives examples of how the use of applied knowledge of Islam that provide direct benefits in everyday life, for example when the fasting month of Ramadan began. In promotion roadshow, they also take interactive discussion discussion with high school students.
Promotion roadshow to schools that did by Marcomm FIAI included in the elements of the promotional mix. That is personal selling which is a form of direct communication between sellers with prospective buyers (person - to - person communication). Seller seeks to help and persuade potential buyers to purchase the products offered. (Morissan, 2014: 34). In this case Marcomm FIAI attempt to persuade prospective students for admission to study in FIAI. Unlike advertising, personal selling strategy involves direct contact between seller and buyer. With direct interaction, Marcomm FIAI can listen to the of the students of these schools.

Personal selling in IMC has individualized characteristic and personalized communications that enable the seller to adjust the message based on specific needs or special situations prospective buyers. Personal selling allows the direct feedback and more precise because of the impact of a sales presentation can be judged directly by the reaction of potential buyers. If feedback occurs is considered less good, then the seller can modify the messages. Personal selling can also be addressed to the prospective buyer that is considered become the most potent and most prospective to become customers in the future.

Based on the description of the theory of personal selling in IMC, the roadshow conducted by Marcomm FIAI did to be able to communicate directly with consumers through the presentation in classes, and can directly provide the information needed by consumers i.e high school students or teachers. Marcomm FIAI also can directly modify the information that must be submitted after receiving the response from prospective students.

\section{c. Direct Marketing}

Other than personal selling, Marcom FIAI also did direct marketing. Muhammad Safarullah as main coordinator of Marcom FIAI explained that: "Due to our segmentation are young people, so we use social media which mostly young people use it. When we did the roadshow, we noted all of the email address of this school students and after that we send our faculty brochure via email" "

Direct marketing is part of the personal selling. It Already described in the preceding section that 
Marcomm FIAI making a presentation when the roadshow to several Islamic School in Java areas. When roadshow, they also collect email addresses from the high school students and then they send digital brochure via email. It is included in elements of direct marketing includes the activities of mail delivery (direct mail), save catalog companies, including database management and telemarketing can be through one of the Internet media (Morissan, 2010: 22). Through brochures sent via email, the organization wishes to be able to communicate directly with potential customers and get direct feedback from them.

\section{d. Advertising}

Integrated marketing communication strategy not only made directly and personally (can be face to face or through the media), but also through intermediary by mass media.

Described by Rizka that "FIAI ever put an ad in education magazine, they promote the content of the new admissions in many colleges, in contract we paid once per year. FIAI ads set on the first page, while Ahmad Dahlan University campus on second page ". Advertising is also one of the common strategy of promotional mix. Advertising is a form of nonpersonal communication about an organization, product or idea that paid by the sponsor (Morissan, 2014: 17). Ad involve the mass media. In this case FIAI used print media i.e education magazine that can send messages to a large number of groups of individuals simultaneously. Although advertising is non-personal communication, but the selection of ad as elements of IMC can be seen still a form of the best known promotion and most widely covered people.

Judging from the advertising advantages, it can be understood why until now the form of promotion through advertising in the mass media still provide extensive exposure. FIAI put an ad in a education magazine with consideration could be marketed more widely, so the content of ad can be read by readers of the magazine in which it was entered as the excellence of the public presentation. Moreover, seen from the placement of news content of ad, that is good promotional techniques because placed on first page and in addition because it was in education magazine which contains alot of collection information of school and campus in the region. FIAI ad content on the first page while Ahmad Dahlan University on the second page where it makes the audience have space to compare one message to another from a number of competing producers (in this case is education institution). It was included in the primacy ad as the pervasiveness.

e. Interactive Marketing

Because the high cost of advertising in the mass media as described in the preceding section, other integrated marketing communication strategy chosen by FIAI is an interactive marketing through social media on the internet. Rizka explain why Marcomm FIAI start focusing interactive marketing that: "Marketing in social media as well as to bridge the guidance of the age when the current one cannot be separated from social media internet. Today if people want to know everything they just search on internet. So if we want a lot people know about us, it means we have to add social media accounts and more productive. We update news and blow-up on any greatest news of our faculty.

The use of social media on the internet becomes very difficult to separate in daily life because internet presents easy-accessibility information. For one of marketing strategy, Marcomm FIAI focus on social media as part of the internet media. That is because social media reflect a variety of new sources of online information that is created, instantiated and used by consumers with the goal of educating each other about products, services, brands, personalities and relevant issues. Therefore, social media is often called consumer-generated media (Tjiptono, 2015: 395). 


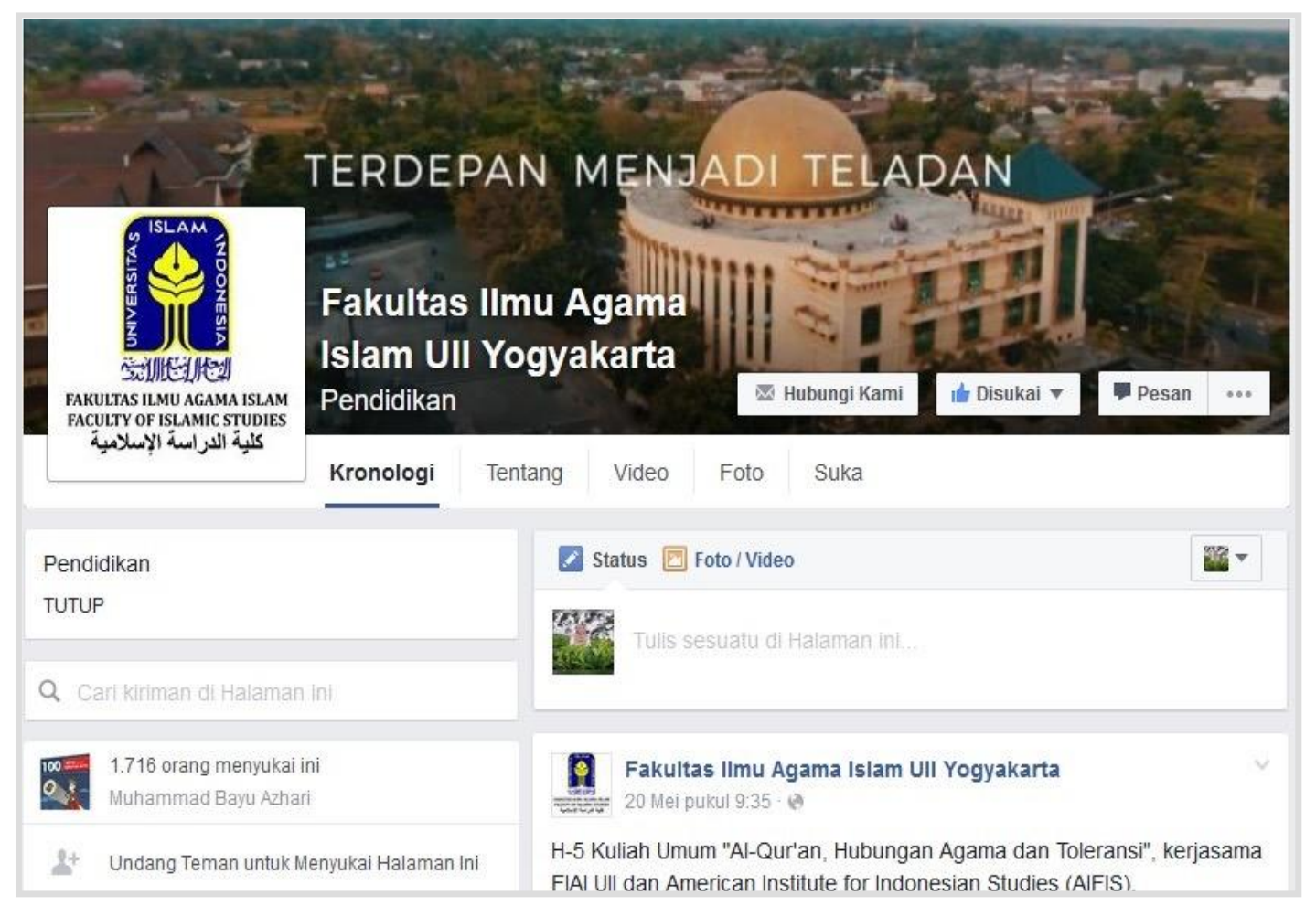

Figure 3: Facebook Fanpage of FIAI UII

Related to that, marketing through social media conducted by FIAI more show good information.

When speaking of social media, we also need to talk about what kind of the content on media. Associated with social media, it will be explained further by Krisnanda as head of media division of Marcomm FIAI.

To popularize FIAI video company profile, they upload it to Youtube. Youtube is media sharing sites that allow users to share content of media such as photos, video and pictures. Through the video company profile, they try to give illustration how study in FIAI more dynamic and diverse. They choose Youtube because it is a medium with a very low cost (even zero cost) when compared with advertising in the mass media, but also can be consumed by a broad audience as well as advertising.

Besides Youtube, Krisnanda explained that Marcom FIAI also use other social media because high school students today as social media users. Video company profile (at the time) became one of the content on social media Facebook which is got great response in two weeks, and in top position on the fan page. Marcomm FIAI handle several social media accounts such as Facebook Fanpage, Line, Path and Instagram.

Krisnanda said that besides video company profile, FIAI social media also regularly upload its branding contents, among others: achievement information of students and lecturer, Marcomm FIAI visit to schools, high school visit to UII, and also the activities held by FIAI that can be regarded as marketing and branding activities. 


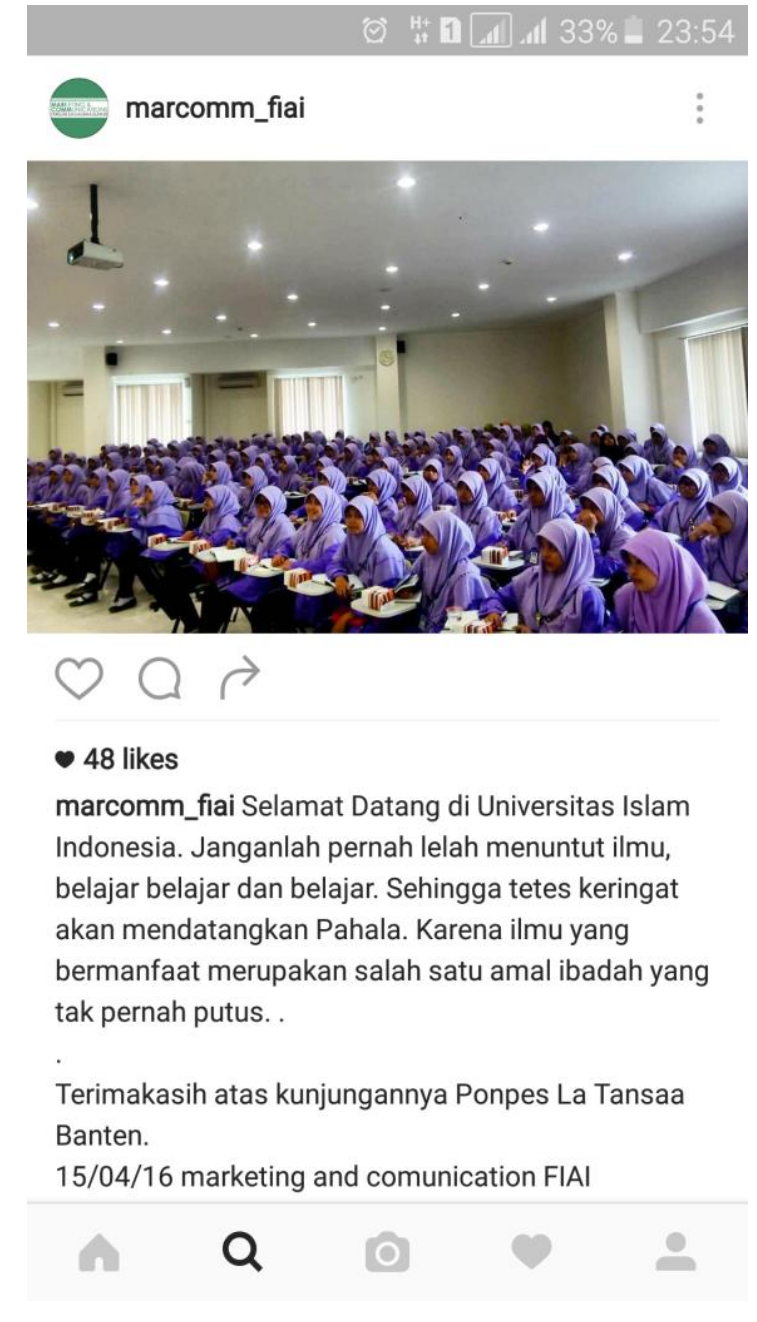

Figure 4: Boarding School La Tansa Banten visit to UII

\section{Conclusion}

Overall, based on the analysis of integrated marketing communication (IMC) strategies can be seen that the segmentation and target market of FIAI UII has been clearly established those are students from Islamic high schools and boarding school. FIAI has competitors such as STAIN, UIN, UMY, and UAD. FIAI adjust the tuition fees based on competitors so also cannot very high. According with IMC theory, the promotional mix did by Marcomm FIAI among others (1). FIAI Marcomm team which consist of students become public relation to connect directly from the faculty to the consumer. (2) Marcomm FIAI did personal Selling by a roadshow presentation to Islamic high schools, Islamic Boarding Schools and Madrasah Aliyah which suitable with segmentation has been determined from previous situation analysis.
(3) Direct marketing by sending digital faculty brochures to email addresses high school students who previously obtained when did a roadshow to several schools in the province of West Java, Central Java and East Java. (4) Advertising by set advertising in education magazine once a year (5). Interactive Marketing through social media Line, Path, Instagram and fanpage Facebook, with content such as: video company profile of FIAI, Marcomm FIAI activities, activities of the University and achievements of faculty.

\section{References}

Clow, Kenneth E \& Baack, Donald. 2001. Integrated Advertising, Promotion, and Marketing Communications. New Jersey: Prentice Hall

Kotler, Philip \& Kevin Lane Keller.2012. Marketing Management. USA: Pearson

Lancaster, Geoff \& Lester Masingham.1993. Essential Of Marketing, 2nd Edition. Singapore

Morissan. 2010. Periklanan: Komunikasi Pemasaran Terpadu. Jakarta: Kencana

Shimp, Tereence A. 2007. Intergrated Communication In Advertising and Promotion, 7th Edition. China: Thomson Higher Education.

Sulaksana, Uyung.2003. Intergrated Marketing Communications. Yogyakarta: Pustaka Pelajar.

Susanto, AB. 2004. Value Marketing. Bandung: Mizan Media Utama.

Tjiptono, Fandy. 2015. Strategi Pemasaran Edisi 4. Yogyakarta: Andi

Rekapitulasi status mahasiswa per program studi. 2016. www.unisys.uii.ac.id . Accessed on 28 April 2016

UII raih akreditasi institusi tertinggi PTS. 2015. http://litbang.kemdikbud.go.id/index.php/bsnp/14sekretariat/25-uii-raih-akreditasi-institusi-tertinggipts. Accessed on tanggal 28 April 2016 